\title{
Research Communication Role of Interleukin-18 in Modulation of Oral Carcinoma Cell Proliferation
}

\author{
Athip Nilkaeo and Suthinee Bhuvanath \\ Department of Microbiology, Faculty of Science, Prince of Songkla University, Hat Yai, Songkla 90112, Thailand
}

Received 22 January 2006; Accepted 24 February 2006

\begin{abstract}
Interleukin-18 (IL-18), a proinflammatory cytokine, is produced by oral epithelia and carcinoma cells and implicated in tumor regression. Since its direct biological effect on oral cancer cells is not well defined, in this study, we employed a KB cell line to test IL-18 activity. Recombinant human IL-18 significantly inhibited KB cell proliferation in a dose-dependent fashion $(P<.05)$ without increasing cytotoxicity. Analysis of its mode of action showed that IL-18 induced cell cycle arrest in the $S$ phase; however, it did not trigger apoptotic cell death. Findings in this study indicate that the suppression of KB cell proliferation was attributed to the modulation of cell cycle progression, providing a new role of this cytokine in antitumor mechanisms.
\end{abstract}

Copyright (c) 2006 A. Nilkaeo and S. Bhuvanath. This is an open access article distributed under the Creative Commons Attribution License, which permits unrestricted use, distribution, and reproduction in any medium, provided the original work is properly cited.

\section{INTRODUCTION}

Interleukin-18 (IL-18) is a pleiotropic inflammatory cytokine produced by both immune and nonimmune cells. It shares several properties with a proinflammatory cytokine IL-1, and is therefore categorized as a member of the IL-1 family. This cytokine was first discovered as a potent IFN$\gamma$-inducing factor in the serum and livers of mice exposed to Propionibacterium acnes and LPS [1]. The known activators of IL-18 production are LPS, IL-1, IL-6, TNF- $\alpha$, and interferons. IL-18 is initially produced as pro-IL-18 $(24 \mathrm{kDa})$ which is then processed by caspase- 1 and other caspases to a mature form with a molecular weight of $18 \mathrm{kDa}$ [2]. IL-18 exerts its biological effect via its receptor complex. IL-18 receptor (IL-18R) is comprised of IL-18R $\alpha$ which is identical to the IL-1R-related protein (IL-1Rrp) and a signal transducing subunit IL-18R $\beta$. The binding of IL-18 to its receptor results in recruitment of adaptor proteins such as MyD88, IRAK, and TRAF6 and leads to the increased activation of transcription factor NF- $\kappa \mathrm{B}[3,4]$. It also activates AP-1, MAPK, STAT3, and the stress kinase p38 pathways [5].

IL-18 modulates both innate and specific immune responses [6]. IL-18 and IL-12 act synergistically to induce IFN- $\gamma$ production by T cells, and it can synergize with IL-10 to induce IFN- $\gamma$ production by NK cells $[7,8]$. In addition,
IL-18 is involved in inflammatory responses of some autoimmunity conditions including arthritis and systemic lupus erythematosus (SLE) $[9,10]$. It is also expressed at the maternal-fetal interface and function to enhance decidual lymphocyte cytotoxic activity [11]. With its primary function in activation of NK cells and induction of IFN- $\gamma$ production by T cells, several recent studies have shown that IL18 is a potential player in modulating the immune system to destroy cancer cells [12].

In human oral carcinoma, patients often display high antibody functions and high levels of Th2 cytokines from an advanced-stage tumor [13]. IL-18 is produced by oral epithelia and carcinoma and this cytokine may function to enhance IFN- $\gamma$ production by NK cells [14]. Furthermore, sera levels of IL-18 as well as other Th1 cytokines are upregulated in nude mice bearing salivary adenocarcinoma treated with streptococcal product and this results in a significant reduction of tumor growth [15]. In addition, it was demonstrated that polymorphonuclear leukocyte production of IL18 was enhanced in oral cavity cancer patients after cancer treatment [16]. These data indicate that IL-18 is an antineoplastic cytokine. However, an antitumor property of IL18 on oral carcinoma has not been directly shown. In this study, we have chosen the $\mathrm{KB}$ oral carcinoma cell line, as an example of oral carcinoma, to study the effect of IL18. 


\section{MATERIALS AND METHODS}

\section{Cytokines and cell line}

Recombinant human IL-18, IL- $1 \beta$, and TNF- $\alpha$ were purchased from Peprotech Inc (Rocky Hill, NJ). The KB cell line is a carcinoma cell line derived from the oral cavity and was kindly provided by Dr Sithichai Khuntongkaew, Faculty of Dentistry, Thammasat University, Thailand. The cells display epithelial morphology. The cells were maintained in DMEMF12 (Life Technologies, Gaithersburg, Md) with 10\% FBS (Biochrom AG Seromed, Berlin, Germany) and antibiotics (100 unit/mL of penicillin $\mathrm{G}$ and $100 \mu \mathrm{g} / \mathrm{mL}$ of streptomycin sulfate) and cultured at $37^{\circ} \mathrm{C}$ in $5 \% \mathrm{CO}_{2}$.

\section{Expression of IL-18R and apoptotic genes}

The expression of IL-18 receptors and apoptotic genes in KB cells was investigated using RT-PCR. Cells were cultured in complete DMEM-F12 medium with or without cytokine treatment. The total RNA was isolated from KB cells by using an acid-guanidium thiocyanate phenol/chloroform extraction protocol [17], and examined for purity using $1 \%$ denaturing agarose gel electrophoresis, and then subjected to one-step RT-PCR (Qiagen, Hilden, Germany) for the expression of genes that paralleled the G3PDH house keeping gene. The following specific oligonucleotide primers were used: IL$18 \mathrm{R} \alpha$ upstream (5' GTTGAGTTGAATGACACAGG $3^{\prime}$ ) and IL-18R $\alpha$ downstream (5' TCCACTGCAACATGGTTAAG 3') generating a 420 -bp PCR product; IL-18R $\beta$ upstream $\left(5^{\prime}\right.$ TGCTCCTGTACATCCTGCTTG $3^{\prime}$ ) and IL-18R $\beta$ downstream $\left(5^{\prime}\right.$ TCTGCTCAGCAACATCTCTAT $\left.3^{\prime}\right)$ generating a 783-bp PCR product; G3PDH upstream (5' TGAAGGTCGGAGTCAACGGATTTGGT $\left.3^{\prime}\right)$ and G3PDH downstream (5' CATGTGGGCATGAGGTCCACCAC $3^{\prime}$ ) generating a 983bp PCR product; bax upstream (5' GGCCCACCAGCTCTGAGCAGA 3') and bax downstream (5' GCCACGTGGGCGTCCCAAAGT $3^{\prime}$ ) generating a 479-bp PCR product; bcl-2 upstream (5' GTGGAGGAGCTCTTCAGGGA $3^{\prime}$ ) and bcl2 downstream (5' AGGCACCCAGGGTGATGCAA 3') generating a 304-bp PCR product. Amplification of cDNA was performed for 32 cycles at $94^{\circ} \mathrm{C}$ for $30 \mathrm{~s}, 58^{\circ} \mathrm{C}$ for $30 \mathrm{~s}$, and $72^{\circ} \mathrm{C}$ for $30 \mathrm{~s}$ for IL- $18 \mathrm{R} \alpha$ and IL- $18 \mathrm{R} \beta ; 35$ cycles at $94^{\circ} \mathrm{C}$ for $45 \mathrm{~s}, 60^{\circ} \mathrm{C}$ for $45 \mathrm{~s}$, and $72^{\circ} \mathrm{C}$ for 2 min for G3PDH; 35 cycles at $94^{\circ} \mathrm{C}$ for $30 \mathrm{~s}, 62^{\circ} \mathrm{C}$ for $30 \mathrm{~s}$, and $72^{\circ} \mathrm{C}$ for $30 \mathrm{~s}$ for bax; and at $94^{\circ} \mathrm{C}$ for $30 \mathrm{~s}, 60^{\circ} \mathrm{C}$ for $30 \mathrm{~s}$, and $72^{\circ} \mathrm{C}$ for $30 \mathrm{~s}$ for bcl-2. PCR products were examined by $1.2 \%$ agarose gel electrophoresis in 0.5X Tris-borate-EDTA (TBE) buffer, and visualized by ethidium bromide staining.

\section{MTT proliferation assay and lactate dehydrogenase assay}

Briefly, KB cells (10000 cells/well) were cultured in collagen I $(50 \mu \mathrm{g} / \mathrm{mL})$ coated 96-well culture plates, in a total volume of $200 \mu \mathrm{L}$ DMEM-F12 supplemented with 1\% FBS. Cells were cultured in the presence of increasing concentrations of recombinant human IL-18 (0-100 ng/mL). Both treatment and control groups were performed in 6-8 replicate wells. The relative number of viable cells was then determined at 72 hours after incubation, by adding $1 \mathrm{mg} / \mathrm{mL}$ of 3-[4,5-dimethylthiazol-2-yl]-2,5-diphenyl tetrazolium bromide (MTT) and incubating the cell further for 4 hours. The formazan crystals formed were then solubilized with acid isopropanol for 1 hour. The absorption value of the solution at $595 \mathrm{~nm}$ directly represents relative cell numbers. The cell decrease percent relative to the control group was then determined.

Lactate dehydrogenase (LDH) released from the cells was used to detect cytotoxicity and was measured at the end of each proliferation experiment. Briefly, culture plates were centrifuged at $1500 \mathrm{rpm}$ for 15 minutes at room temperature to ensure accumulation of cells at the bottom of the wells. Cell-free culture media $(100 \mu \mathrm{L})$ was collected and then incubated with $100 \mu \mathrm{L}$ of the reaction mixture of the cytotoxicity detection kit (Boehringer Mannheim, Indianapolis, Ind) for 30 minutes at room temperature in the dark. $1 \mathrm{~N} \mathrm{HCl}(50 \mu \mathrm{L})$ was added into each well to stop the enzymatic reaction. The optical density of the solution was then measured by using an ELISA plate reader with a $490 \mathrm{~nm}$ filter. Cytotoxicity percent to the control was then determined.

\section{Cell death assays}

For the in situ apoptotic cell death detection assay, KB cells were cultured on a glass slide in 6-well plate until $70-80 \%$ confluence had been achieved. The culture medium was replaced with fresh medium containing $1 \%$ FBS with or without IL-18 (100 ng/mL) and incubated for 72 hours. Apoptotic cell death was detected using an apoptosis staining kit ( $R \& D$ systems, Minneapolis, Minn) in the culture plate and visualized using laser confocal microscopy. Similar experiments were conducted without glass slides and apoptotic cells were determined using flow cytometry.

In DNA laddering analysis, $\mathrm{KB}$ cells were cultured in 6well culture plate until 70-80\% confluence. The medium was replaced with fresh medium supplemented with $1 \%$ FBS in the presence of IL-18 (0-100 ng/mL) and incubated for 24, 48 , and 72 hours. Cells were then washed with cold PBS and lysis solution was added. DNA samples were then extracted from the solution using a phenol-chloroform-isoamyl alcohol extraction protocol. DNA concentration was determined using a spectrophotometer $\left(\mathrm{OD}_{260}\right)$. DNA $(1 \mu \mathrm{g})$ samples were then fractionated by agarose gel $(1.5 \%)$ electrophoresis. The gel was then stained with ethidium bromide and visualized using a UV transilluminator, and photographs were taken using a gel documentation system.

\section{Cell cycle analysis}

KB cells (350000 cells/well) were grown in 6-well culture plate and synchronized using serum starvation and hydroxyurea $(0.1 \mathrm{mM})$ treatment for 24 hours. Synchronized KB cells were restimulated with medium containing $2 \%$ FBS or $2 \%$ FBS plus IL-18 (100 ng/mL) and incubated for various times $(0,8,24,32$, and 48 hours). Cells were then trypsinized, 


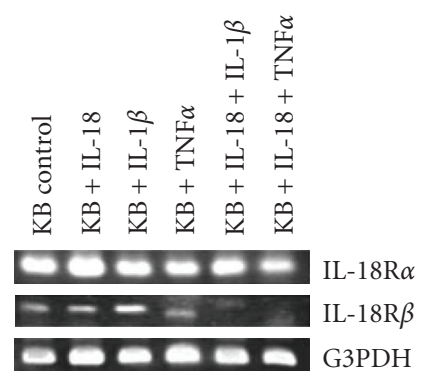

(a)

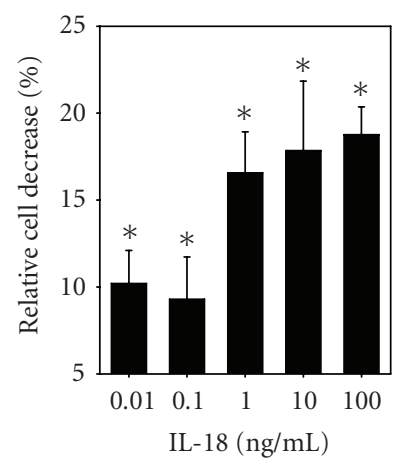

(b)

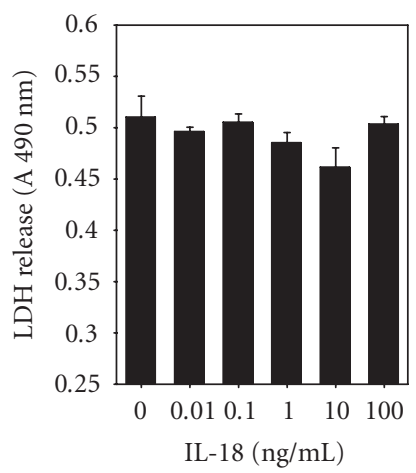

(c)

FIgURE 1: Expression of IL-18 receptors and biological activity of IL-18 on KB cells. (a) Two $\mu$ g of total RNA samples from KB cells, with or without cytokines treatment, were subjected to RT-PCR for IL-18R mRNA expression. (b) KB cells were cultured for 72 hours in media containing increasing concentrations of IL-18. Relative cell numbers were measured by MTT assays and the relative cell decrease (mean \pm SEM) was then determined. (c) Cytotoxicity of IL-18 was determined at the end of the proliferation assay using an LDH detection kit. Asterisk $(*, P<.05)$ represents significant difference between the treatment and control groups as analyzed by one-way ANOVA.

centrifuged, and resuspended in PBS. Cells were then fixed, stained with propidium iodide solution, and processed for flow cytometry analysis. The cell percent in each cell cycle phase was determined in each sample (30000 counts), and comparison was made between the 2 groups.

\section{Statistical analysis}

Data are presented as means \pm standard error of the mean (SEM). In cell proliferation and cytotoxicity experiments, Dunnett's method of one-way analysis of variance (ANOVA) was used to assess differences among control groups and treatment groups. Differences in data between two groups in the cell cycle studies were analyzed using the Student $t$ test. All experiments were repeated at least three times for reproducibility.

\section{RESULTS}

\section{Expression of IL-18R and biological activity of IL-18 on KB cells}

Expression of IL-18R was investigated under normal culture condition and in the presence of IL-18 $(10 \mathrm{ng} / \mathrm{mL})$, TNF$\alpha(10 \mathrm{ng} / \mathrm{mL})$, or IL- $1 \beta(10 \mathrm{ng} / \mathrm{mL})$, separately or in various combinations for 24 hours. In normal conditions, without cytokine stress, (Figure 1(a)) KB cells constitutively expressed IL-18-receptor (both IL-18R $\alpha$ and IL-18R $\beta$ ) transcripts. However, IL-18R expression was regulated with cytokine treatment. By normalization of the band intensity of each gene to that of G3PDH, IL-18R $\alpha$ expression was augmented by IL- 18 alone or in combination with TNF- $\alpha$. In contrast, TNF- $\alpha$ alone, IL- 18 plus IL- $1 \beta$, and IL- 18 plus TNF- $\alpha$ down-regulated IL-18R $\beta$ expression. Results from this experiment clearly indicated that the $\mathrm{KB}$ cell line is a specific target for IL-18 by regulating the expression of IL-18R.

To test the biological effect of IL-18 on KB cells, we utilized nonradioactive MTT assays. IL-18 treatment in KB cells (Figure 1(b)) resulted in suppression of cell proliferation in a dose-dependent fashion. As low as $10 \mathrm{pg} / \mathrm{mL}$, IL18 caused a $10 \%$ reduction of cell numbers compared to the control group $(P<.05)$. At the highest concentration $(100 \mathrm{ng} / \mathrm{mL})$ of cytokine used in this study, the decrease of cell numbers reached a maximum of $19 \%$. No further decrease of cell numbers occurred when the IL-18 dose was doubled to $200 \mathrm{ng} / \mathrm{mL}$. Further analysis on IL-18 cytotoxicity, by measuring $\mathrm{LDH}$ release from $\mathrm{KB}$ cells at the end of each proliferation experiment, interestingly, showed no significant concentration-dependent changes in LDH level (Figure $1(\mathrm{c})$ ). This indicated that the inhibition of $\mathrm{KB}$ cell proliferation was not mediated by the induction of cytotoxicity.

\section{Involvement of IL-18 on cell death}

To further study the involvement of IL-18 on cell death, we employed 2 techniques that are capable of illustrating DNA fragmentation in apoptotic cells. In detection of in situ cell death, treatment of KB cells with IL-18 resulted in no significant induction of apoptotic cell death compared to the nontreatment group (Figures 2(b) and 2(c)). This experiment was confirmed by using the flow cytometric method. There was no significant difference in mean fluorescent intensity between the nontreated control group and the IL-18 treated group (data not shown). In the DNA laddering analysis (Figure 2(d)), fragmented DNA was not observed in KB cells treated with IL-18 after 24,48 , or 72 hours. In addition, spontaneous cell death could not be demonstrated by DNA laddering. This result is consistent with the in situ apoptotic cell death detection assay, indicating that IL-18 treatment (in the dose range from $0.01-100 \mathrm{ng} / \mathrm{mL}$ ) of $\mathrm{KB}$ cells did not trigger apoptotic cell death. In addition, analysis of apoptotic gene expression in KB cells treated with IL-18 at various time points was also conducted using RT-PCR. Normalization of the band intensities of bcl-2 and bax gene to that of 


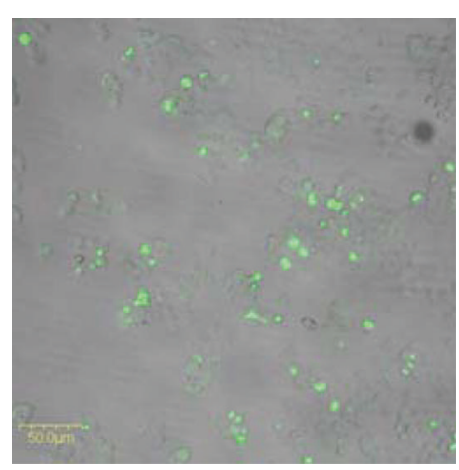

(a)

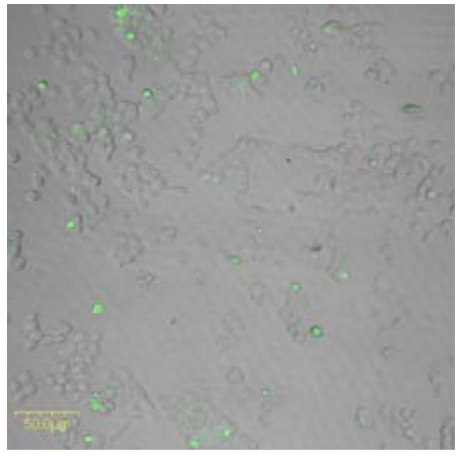

(b)

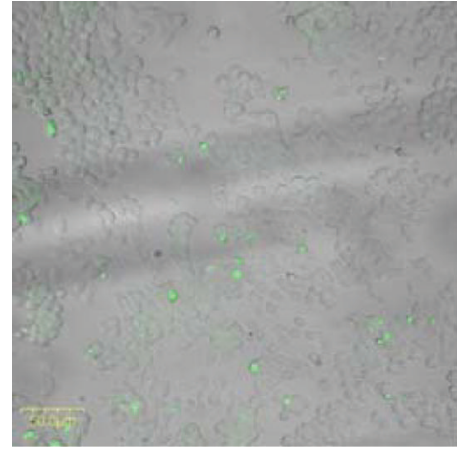

(c)

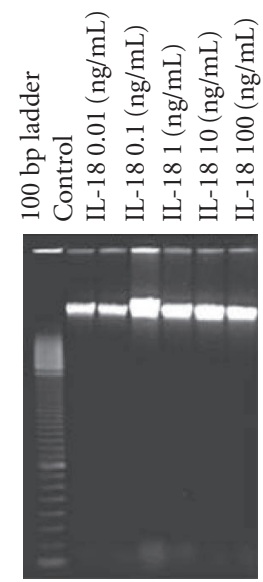

24 hours

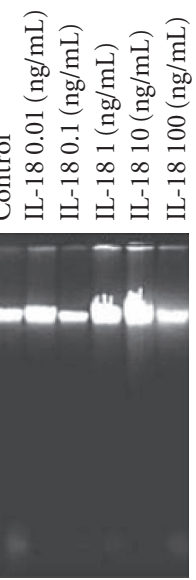

48 hours

(d)

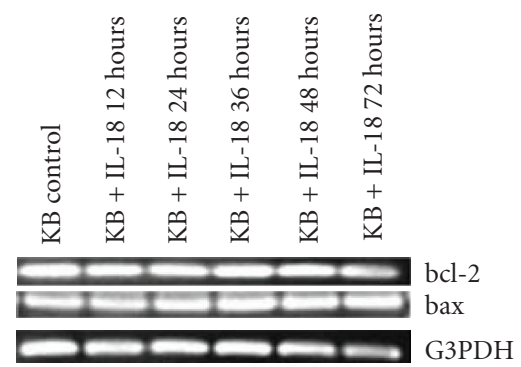

(e)

FIGURE 2: Involvement of IL-18 in apoptotic cell death of KB cells. KB cells were cultured for 48 hours on slides, with or without IL-18. Cells were then subjected to the in situ cell death detection assay. Apoptotic cells, with a fluorescent nucleus, were visualized using laser confocal microscopy. (a) Positive staining control, (b) nontreatment control, (c) IL-18 (100 ng/mL) treatment. In the DNA laddering analysis (d), DNA samples were extracted from KB cells cultured with or without IL-18 (0-100 ng/mL) treatment and fractionated by agarose gel (2\%) electrophoresis. (e) Total RNA $(2 \mu \mathrm{g})$ samples from KB cells, with or without IL-18 $(10 \mathrm{ng} / \mathrm{mL})$ treatment, were subjected to RT-PCR for expression of apoptotic genes (bcl-2 and bax) along with the gene for G3PDH.

G3PDH was used to determine the level of expression. As we anticipated (Figure 2(e)), the expression of these genes was not altered by IL-18 $(10 \mathrm{ng} / \mathrm{mL})$ treatments at any time point tested, suggesting that IL-18 was not involved in altering the expression of apoptotic genes in KB cells.

\section{IL-18 modulation of cell cycle progression}

Since the inhibitory effect of IL-18 on KB cells was not due to the induction of cell death, we therefore hypothesized that inhibition could be attributed to the modulation of cell cycle progression. To examine the effect of IL-18 on the control of $\mathrm{KB}$ cell cycle progression, the numbers (\%) of cells in each stage (G0/G1, S, and G2/M) of the cell cycle of both control group and treatment group were compared. We found that the majority of synchronized cells (approximately 65\%) were arrested in the $\mathrm{S}$ phase, leaving a small number of cells in the G2/M phase (approximately 5\%). Within 8 hours of restimulation by $2 \%$ FBS, cells were released from their S phase arrest (Table 1). However, in the presence of IL-18, the cell cycle progression was delayed. The number of cells that exited the $S$ phase was lower in the cytokine treated group compared to the control $(P<.001)$. At 24 hours after cell cycle restimulation, the number of cells in the $S$ phase in the IL-18 treated group was higher than that of the control group $(P<.001)$. At 32 and 48 hours, there was no significant difference in the proportion of cells in each cell cycle phase between the IL-18-treated and the control group. Although the $S$ phase arrest phenomenon lasted only for the first 24 hours, from this evidence we concluded that $\mathrm{KB}$ cells do exhibit a slower proliferation rate in the presence of IL-18. 
TABLE 1: Effect of IL-18 on KB cell cycle progression. Synchronized KB cells were restimulated with $2 \%$ FBS, with or without IL-18 $(100 \mathrm{ng} / \mathrm{mL})$. Percentage of cells (mean \pm SEM) in each cell cycle phase was determined. Asterisk $(*, P<.001)$ represents significant difference between IL-18 treatment and control groups as analyzed by T test.

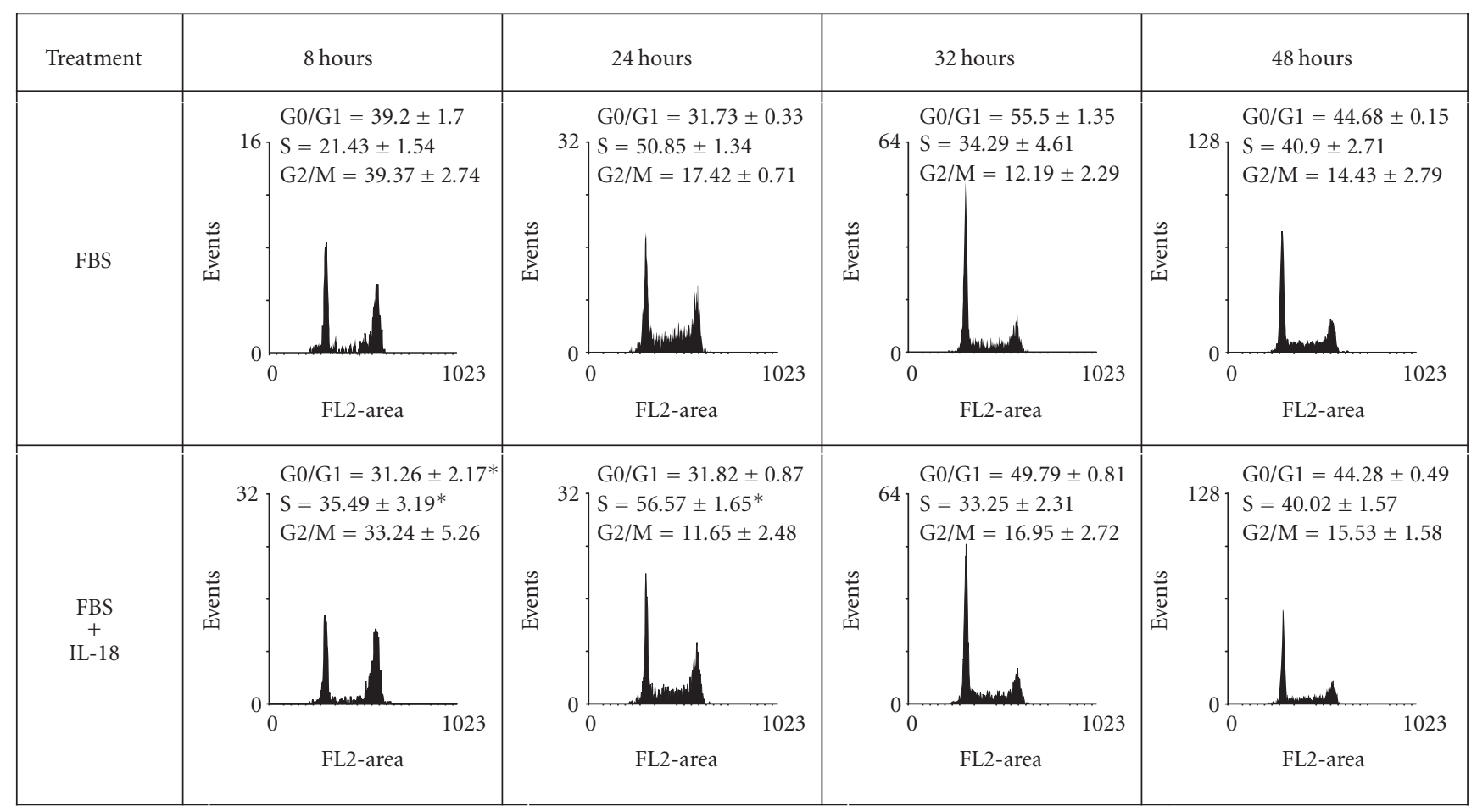

\section{DISCUSSION}

Because of its remarkable ability to activate IFN- $\gamma$ production by immune cells and to enhance NK cell activity, IL18 has been identified as a good candidate for cancer immunotherapy. To date, there have been no reports on the direct effect of this cytokine on cancer cells. In this study, using $\mathrm{KB}$ cells as the representative of oral carcinoma cells, we have demonstrated, for the first time, a direct in vitro interaction of IL-18 with KB cells on their proliferation, cell death, and cell cycle progression. IL-18 treatment in KB cells resulted in a reduction of cell proliferation. Like other solid tumor studies, IL-18 was shown to exhibit its antitumor properties. In a study of human pancreatic carcinoma cells, it was demonstrated that during the drug treatment, cancer cells could produce IL-18, which in turn enhanced IFN- $\gamma$ production by $\mathrm{T}$ cells [18]. This indicates that IL-18 acts as a mediator for antitumor mechanisms. In addition, IL-18 could exert its action in concert with other cytokines, such as IL-23, or a nitric oxide synthase inhibitor to enhance antitumor immunity $[19,20]$. Interestingly, in a nonsolid tumor model, this cytokine did not have inhibitory effects, as shown in human leukemia cell lines [21]. We have also shown that IL-18 treatment did not lead to cytotoxicity or induction of apoptotic cell death or alteration of apoptotic gene expression in $\mathrm{KB}$ cells. Similarly, this phenomenon was observed in a study in vitro IL-18 treatment of B16 mouse melanoma cell line [22]. In a mouse model of neuroblastoma, IL-18 treatment led to tumor death, however it is likely caused by the activation of
NK cells in the tumor microenvironment, rather than the direct effect of IL-18 [23]. In addition, previous studies have demonstrated that IL-18 promotion of apoptosis maybe mediated by the induction of TNF and FasL pathways [24-26] or Fas expression [27].

Furthermore in our report; we revealed that mechanism of IL-18 inhibitory effect is attributed to the modulation of cell cycle progression leading to $S$ phase arrest. It has been demonstrated in several studies that $S$ phase arrest is often accompanied with the interference of cell cycle control proteins. For example, hypoxia-induced $S$ phase arrest in human breast (T-47D) and cervical (NHIK 3025) cancer cell lines was paralleled with the down-regulation of cyclin A [28]. A study on rat fibroblast showed that in a low serum condition, the cells entered $S$ phase arrest with a decrease cyclin A, cyclin B, and cdc2, whereas the level of cyclin D2, cdk4, and cdk2 persisted at high level [29]. Though the mechanisms in $\mathrm{KB}$ cells have not been elucidated, it is likely that IL-18 signal transduction may result in interference with the regulation of the cyclin proteins and/or the replication of chromosome during $S$ phase. This, therefore, resulted in a transient delay of a transition of $\mathrm{S}$ to $\mathrm{M}$ phase, leading to a slow proliferative rate.

Collectively, our findings indicate that suppression of $\mathrm{KB}$ cell proliferation was attributed to the modulation of cell cycle progression and not to the induction of cell death. Data presented in this research could provide an insight on how oral carcinoma cells directly respond to IL-18 as this cytokine is an important key regulator of anticancer mechanisms, and 
this could identify a new role for this cytokine, secondary to the modulation of the immune response.

\section{ACKNOWLEDGMENTS}

This work was supported by a grant from the Faculty of Science, Prince of Songkla University (fiscal year 2003). We sincerely thank the Department of Biochemistry and the Scientific Equipment Centre at Prince of Songkla University for all their technical assistance.

\section{REFERENCES}

[1] Nakanishi K, Yoshimoto T, Tsutsui H, Okamura H. Interleukin-18 regulates both Th1 and Th2 responses. Annual Review of Immunology. 2001;19:423-474.

[2] Dinarello CA. Interleukin-18. Methods. 1999;19(1):121-132.

[3] Adachi O, Kawai T, Takeda K, et al. Targeted disruption of the MyD88 gene results in loss of IL-1- and IL- 18-mediated function. Immunity. 1998;9(1):143-150.

[4] Sims JE. IL-1 and IL-18 receptors, and their extended family. Current Opinion in Immunology. 2002;14(1):117-122.

[5] Kalina U, Kauschat D, Koyama N, et al. IL-18 activates STAT3 in the natural killer cell line 92, augments cytotoxic activity, and mediates IFN-gamma production by the stress kinase p38 and by the extracellular regulated kinases p44erk-1 and p42erk-21. Journal of Immunology. 2000;165(3):1307-1313.

[6] Akira S. The role of IL-18 in innate immunity. Current Opinion in Immunology. 2000;12(1):59-63.

[7] Yoshimoto T, Takeda K, Tanaka T, et al. IL-12 up-regulates IL18 receptor expression on T cells, Th1 cells, and B cells: synergism with IL-18 for IFN-gamma production. Journal of Immunology. 1998;161(7):3400-3407.

[8] Cai G, Kastelein RA, Hunter CA. IL-10 enhances NK cell proliferation, cytotoxicity and production of IFN-gamma when combined with IL-18. European Journal of Immunology. 1999;29(9):2658-2665.

[9] McInnes IB, Gracie JA, Leung BP, Wei XQ, Liew FY. Interleukin 18: a pleiotropic participant in chronic inflammation. Immunology Today. 2000;21:312-315.

[10] Esfandiari E, McInnes IB, Lindop G, et al. A proinflammatory role of IL-18 in the development of spontaneous autoimmune disease. Journal of Immunology. 2001;167(9):5338-5347.

[11] Tokmadzic VS, Tsuji Y, Bogovic T, et al. IL-18 is present at the maternal-fetal interface and enhances cytotoxic activity of decidual lymphocytes. American Journal of Reproductive Immunology. 2002;48(4):191-200.

[12] Golab J. Interleukin 18-interferon gamma inducing factor-a novel player in tumour immunotherapy? Cytokine. 2000;12 (4):332-338.

[13] Agarwal A, Rani M, Saha GK, et al. Disregulated expression of the Th2 cytokine gene in patients with intraoral squamous cell carcinoma. Immunological Investigations. 2003;32(1-2):17-30.

[14] Moore MB, Kurago ZB, Fullenkamp CA, Lutz CT. Squamous cell carcinoma cells differentially stimulate NK cell effector functions: the role of IL-18. Cancer Immunology, Immunotherapy. 2003;52(2):107-115.

[15] Okamoto M, Ohe G, Furuichi S, et al. Enhancement of antitumor immunity by lipoteichoic acid-related molecule isolated from OK-432, a streptococcal agent, in athymic nude mice bearing human salivary adenocarcinoma: role of natural killer cells. Anticancer Research. 2002;22(6 A):3229-3239.
[16] Jablonska E, Puzewska W, Grabowska Z, Jablonski J, Talarek L. VEGF, IL-18 and NO production by neutrophils and their serum levels in patients with oral cavity cancer. Cytokine. 2005;30(3):93-99.

[17] Chomczynski P, Sacchi N. Single-step method of RNA isolation by acid guanidinium thiocyanate-phenol-chloroform extraction. Analytical Biochemistry. 1987;162(1):156-159.

[18] Carbone A, Rodeck U, Mauri FA, et al. Human pancreatic carcinoma cells secrete bioactive Interleukin-18 after treatment with 5-fluorouracil: implications for anti-tumor immune response. Cancer Biology and Therapy. 2005;4(2):231-241.

[19] Wang J, Kobayashi Y, Sato A, Kobayashi E, Murakami T. Synergistic anti-tumor effect by combinatorial gene-gun therapy using IL-23 and IL-18 cDNA. Journal of Dermatological Science. 2004;36(1):66-68.

[20] Hegardt P, Widegren B, Li L, et al. Nitric oxide synthase inhibitor and IL-18 enhance the anti-tumor immune response of rats carrying an intrahepatic colon carcinoma. Cancer Immunology, Immunotherapy. 2001;50(9):491-501.

[21] Zhang B, Ma XT, Zheng GG, Li G, Rao Q, Wu KF. Expression of IL-18 and its receptor in human leukemia cells. Leukemia Research. 2003;27(9):813-822.

[22] Jin G-H, Jin S-Z, Liu Y, et al. Therapeutic effect of genetherapy in combination with local $\mathrm{X}$-irradiation in a mouse malignant melanoma model. Biochemical and Biophysical Research Communications. 2005;330(3):975-981.

[23] Redlinger RE Jr, Mailliard RB, Lotze MT, Barksdale Jr EM. Synergistic interleukin-18 and low-dose interleukin-2 promote regression of established murine neuroblastoma in vivo. Journal of Pediatric Surgery. 2003;38(3):301-307.

[24] Tsutsui H, Matsui K, Kawada N, et al. IL-18 accounts for both TNF-alpha- and Fas ligand-mediated hepatotoxic pathways in endotoxin-induced liver injury in mice. Journal of Immunology. 1997;159:3961-3967.

[25] Hashimoto W, Osaki T, Okamura H, et al. Differential antitumor effects of administration of recombinant IL-18 or recombinant IL-12 are mediated primarily by Fas-Fas ligandand perforin- induced tumor apoptosis, respectively. Journal of Immunology. 1999;163(2):583-589.

[26] Lee MO, Choi YH, Shin EC, et al. Hepatitis B virus X protein induced expression of interleukin 18 (IL-18): a potential mechanism for liver injury caused by hepatitis B virus (HBV) infection. Journal of Hepatology. 2002;37(3):380-386.

[27] Menon R, Lombardi SJ, Fortunato SJ. IL-18, a product of choriodecidual cells, increases during premature rupture of membranes but fails to turn on the Fas-FasL-mediated apoptosis pathway. Journal of Assisted Reproduction and Genetics. 2001;18(5):276-284.

[28] Seim J, Graff P, Amellem O, Landsverk KS, Stokke T, Pettersen EO. Hypoxia-induced irreversible S-phase arrest involves down-regulation of cyclin A. Cell Proliferation. 2003;36 (6):321-332.

[29] Kerkhoff E, Ziff EB. Cyclin D2 and Ha-Ras transformed rat embryo fibroblasts exhibit a novel deregulation of cell size control and early S phase arrest in low serum. The EMBO Journal. 1995;9:1892-1903. 


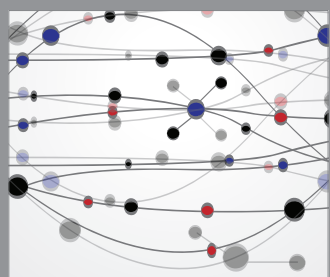

The Scientific World Journal
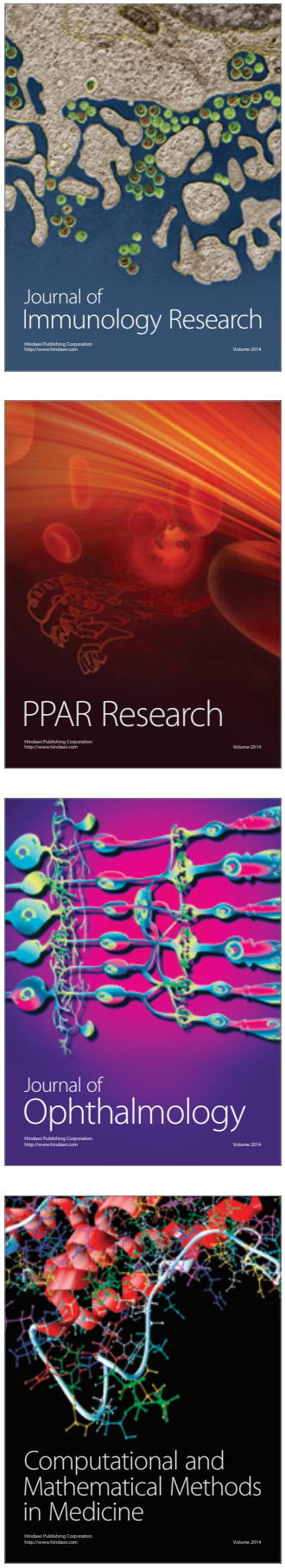

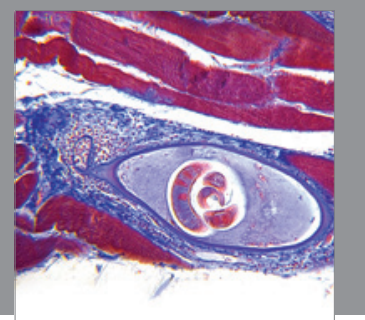

Gastroenterology

Research and Practice
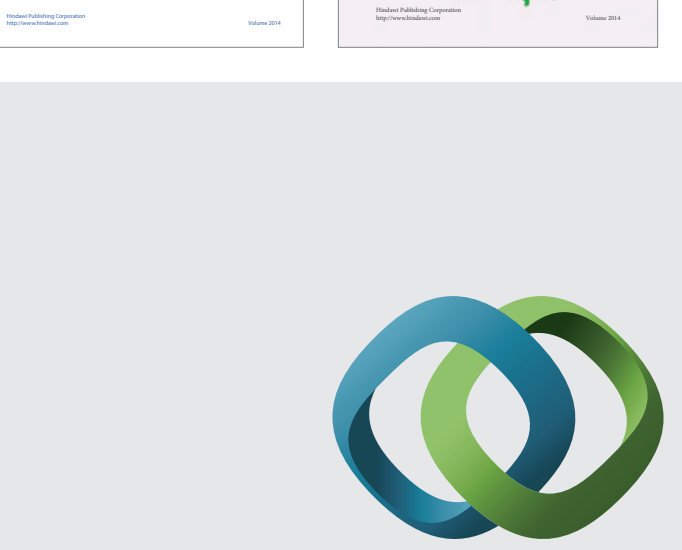

\section{Hindawi}

Submit your manuscripts at

http://www.hindawi.com
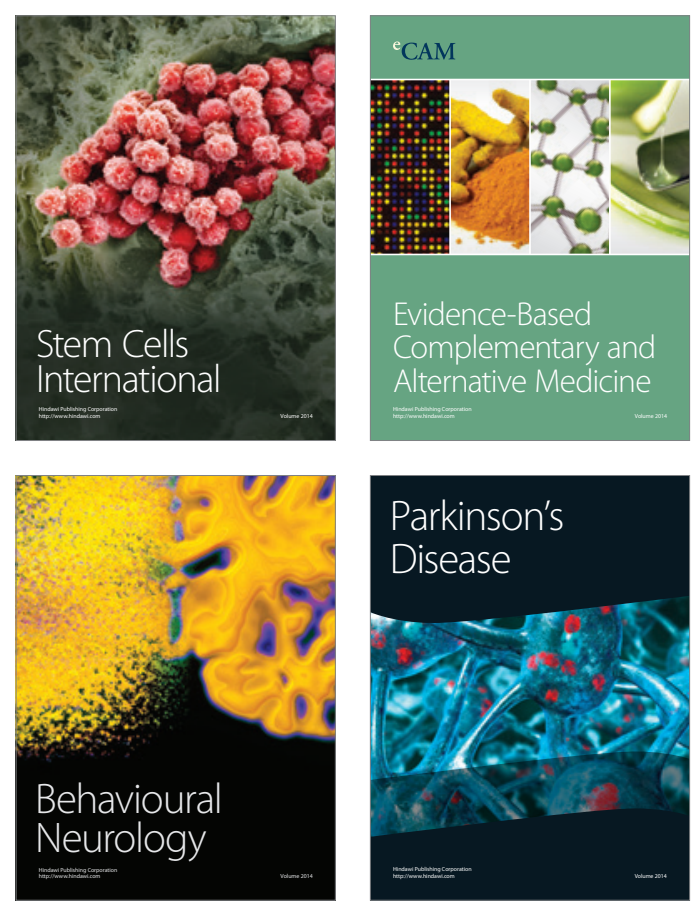

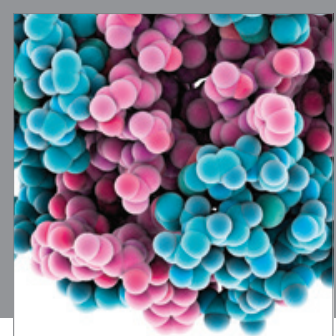

Journal of
Diabetes Research

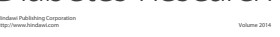

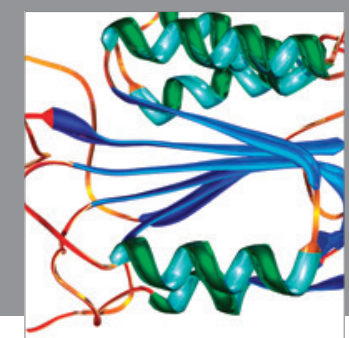

Disease Markers
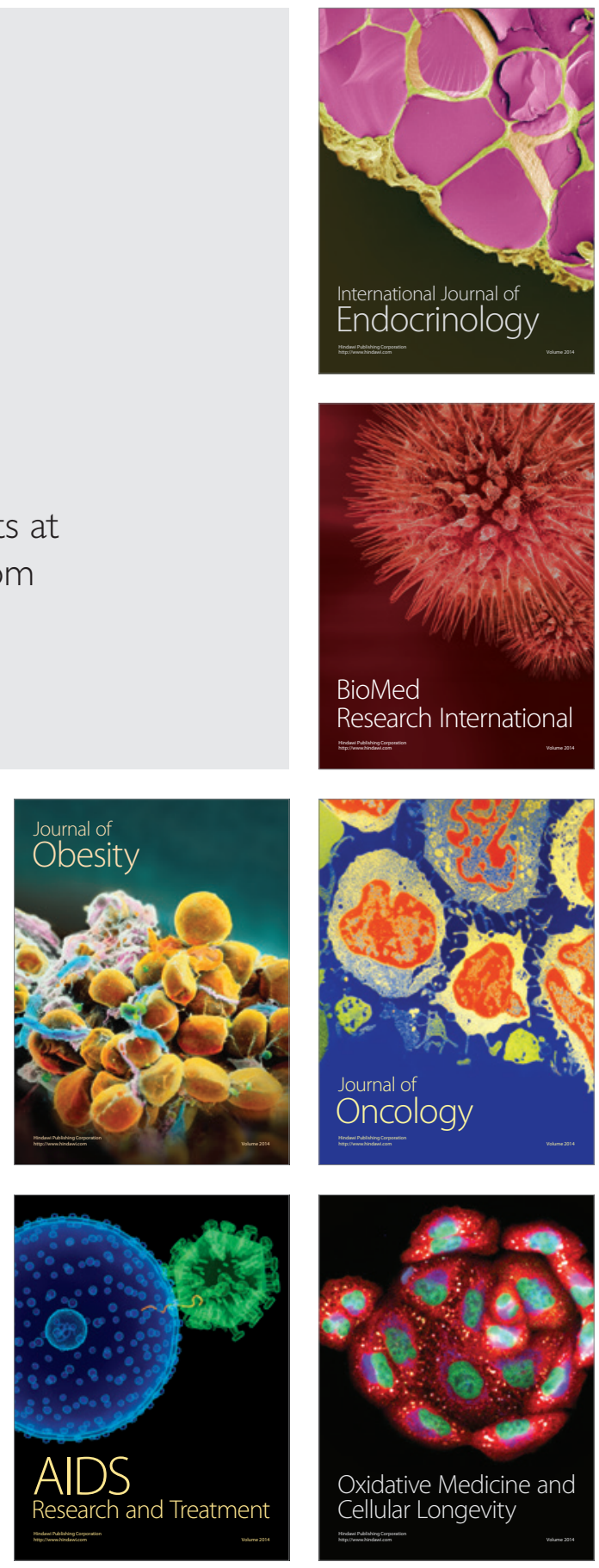